\title{
Fuel age, weather and burn probability in Portugal
}

\author{
Paulo M. Fernandes ${ }^{\mathrm{A}, \mathrm{B}, \mathrm{C}}$, Carlos Loureiro ${ }^{\mathrm{A}, \mathrm{B}}$, Marco Magalhães ${ }^{\mathrm{B}}$, Pedro Ferreira ${ }^{\mathrm{B}}$ and Manuel
}

\section{Fernandes ${ }^{\mathrm{B}}$}

A Centro de Investigação e de Tecnologias Agro-Ambientais e Tecnológicas (CITAB), Universidade de Trás-os-Montes e Alto Douro, Apartado 1013, 5001-801, Portugal

в Departamento de Ciências Florestais e Arquitectura Paisagista, Universidade de Trás-os-Montes e Alto Douro, Apartado 1013, 5001-801, Portugal.

c Corresponding author. Tel.: +351 259 350885; fax: +351 259 350480. Email: pfern@utad.pt

\begin{abstract}
The relative influence of the factors acting upon burn probability, namely fuel and weather, is not well understood, especially in Europe. We use a digital fire atlas (1975-2008) and apply survival analysis to individual fires (1998-2008) to describe how burn probability changes with fuel age in Portugal. The typical FRI (fire return interval) and median fire-free interval vary regionally from 23 to 52 and 18 to 47 years, respectively. Increase of the hazard of burning with time is generally near linear, denoting moderate fuel-age dependency as in some other shrub-dominated Mediterranean environments. Analysis of complete fire intervals resulted in shorter FRI and higher fuel-age dependency of burn probability than findings that included censored observations. Increasingly severe weather conditions either expressed through fire size or by extreme fire danger, concurrently decreased fuel-age dependency and selected for older fuels. The results are discussed from the viewpoints of fire suppression and fuel treatments.
\end{abstract}

\section{Introduction}

The spatial and temporal patterns of landscape fire spread are determined by a complex interplay between the biophysical setting and humans, as agents of both fire ignition and suppression. Fire regimes are determined by a mix of top-down (climate and weather) and bottom-up (ignitions and fuels) controls, which respectively are exogenous and endogenous to the system (Boer et al. 2008). Increased landscape-level accumulation and connectivity of flammable fuels and more frequent extreme weather events are thought to have promoted an increase in large fires in the western Mediterranean Basin over the last decades, e.g. Díaz-Delgado et al. (2004).

A robust cause-effect relationship exists between weather conditions and fire activity in the Mediterranean Basin. Carvalho et al. (2008) and Camia and Amatulli (2009) were able to explain more than $80 \%$ of the monthly area burned variability from components of the Canadian Forest Fire Weather Index (Van Wagner 1987), at Portuguese and Mediterranean European levels. A strongly asymmetrical fire size distribution implies that a relatively small number of fires accounts for most of the area burned: 35 to $85 \%$ of the annual burned surface in Portugal (1984-2004) was due to fires $>100$ ha (Zea Bermudez et al. 2009). These large fires, as shown by Pereira et al. (2005) and Hoinka et al. (2009), occur in association with abnormally hot and dry atmospheric conditions.

Understanding the relative influences of the mechanisms governing fire incidence is a pending scientific question with important land management implications. If fire occurrence is time-dependent, then weather will play a relatively minor role on fire incidence, which will be controlled by the existing fuel age mosaic and thereby could be mitigated by fuel treatments (Minnich 1983). The opposing view defends that fuel age is poorly related to burn probability in 
crown-fire ecosystems such as Mediterranean conifer forests and shrublands, and has gained momentum in recent years (Keeley 2002; Moritz et al. 2004; Keeley and Zedler 2009). Ignition density and drought (Bradstock 2010) and the likelihood and severity of extreme wind events (Moritz et al. 2010) should influence the trade-offs between fuel and weather as drivers of burn probability.

Fire frequency analysis of spatially explicit fire history data has been used to better describe and understand how fuel age affects fire incidence (e.g. Moritz 2003), adding to the debate over the environmental drivers of fire incidence and the relevance of managing fuels. Contemporary fire history data is analysed in this study with the objectives of determining (i) how fuel age affects the recurrence of fire in Portugal and across its ecoregions, and (ii) how weather influences the dependence of burn probability on fuel age. Our expectancies were that fire frequency would vary regionally, and that the likelihood of fire occurrence would be less responsive to fuel age as fire weather is aggravated.

\section{Methods}

Our study area is the entire Portuguese mainland, $89 \times 10^{3} \mathrm{~km}^{2}$. For a description of the Portuguese fire environment see Nunes et al. (2005). We used the Portuguese Forest Service digital atlas of fire perimeters, which is based on high-resolution satellite data from Landsat TM and ETM+ (Pereira and Santos 2003), and ArcGIS 9.2 to process the spatial information. Analysing fire frequency usually involves sampling the landscape mosaic of patches resulting from the intersection of past fire events. Instead, we modelled the distribution of fire intervals from individual fires to allow testing of the weather effect on the time-dependency of burn probability. Annual layers of fire areas were available for the 1975-2008 period and were rasterized to grids of $25 \times 25-\mathrm{m}$ cells. Fire recurrence was determined as the number of times each cell burned. A reasonable period of observation (23 to 33 years) was ensured by restricting the analysis to fires occurring after 1997. We considered fires $\geq 9.5$ ha only, to decrease the computational burden and partially compensate for the existence of variation in the minimum fire size that was mapped (Pereira and Santos 2003). Omission of the smallest fires is a negligible source of uncertainty in fire frequency analysis (Moritz et al. 2009). For the area superimposed by each fire, we calculated the Fire Return Interval (FRI) as

$$
\mathrm{FRI}=(\mathrm{Y}-1975) / \mathrm{R}
$$

where $\mathrm{Y}$ is the fire year (1998 to 2008) and $\mathrm{R}$ is the mean recurrence of fire since 1975 , computed as the average cell fire recurrence. The first fire at any given location was incomplete (rightcensored), i.e. the preceding FRI could not be determined; fires overlaying areas whose majority of cells had burnt at least once since 1975 corresponded to complete and uncensored fire intervals (Polakow and Dunne 1999; Moritz et al. 2009).

We used maximum likelihood survival analysis by fitting a two-parameter Weibull function to the FRI distributions (Johnson and Gutsell 1994; Moritz 2003). Each fire size was divided by 9.5 (the lowest fire size) to obtain weights for model fitting. The Weibull hazard of burning $\lambda(t)=\mathrm{c} t^{\mathrm{c}-}$ $1 / b^{c}$ gives the instantaneous probability of a fire occurring in a specific time interval. The scale parameter $b$ is the typical FRI that will not be exceeded $63.2 \%$ of the time. The shape parameter $c$ is dimensionless and describes the change in burn probability through time. Consequently, the $\lambda(t)$ function has ecological meaning and is useful to measure how fire recurrence is affected by fuel age: hazard increases with time when $c>1$, with $c$ $=2$ and $c>2$ respectively reflecting linear and exponential increases; $c=1$ characterizes a negative exponential distribution where hazard is constant in time, i.e. age-independent. Additionally, we have calculated the median Weibull fire-free interval (MEI), which is adequate as a central tendency measure of asymmetrical fire interval distributions (Grissino-Mayer 1999).

The survival analysis accounted for both uncensored and censored (53.7\% of the total) observations to decrease misrepresentation of long fire intervals (Moritz et al. 2009), especially in view of the relatively short time span of the study. Additionally, fire frequency was modelled just from complete observations. Models were fitted to Portugal and separately to its ecoregions, which 
are defined by climate, geology and landform (Albuquerque 1961).

The effect of weather on the age-dependency of burn probability was tested by assuming fire size as a proxy for weather conditions. Other factors contribute to fire size, but immediate fire suppression is generalized in the cultural landscapes of the Mediterranean, implying that large fires seldom occur under mild weather. We split data into two subsets, successively defined by arbitrary fire size thresholds of $25,50,100,250$ and $500 \mathrm{ha}$, and determined the Weibull parameters for each subset pair, e.g. for fires $<25$ and $\geq 25$ ha.

We also used actual fire weather data by crossreferencing the digital atlas and the Forest Service fire database, which includes individual fires location and time of ignition and extinction. The analysis was restricted to fires $\geq 100$ ha because fire events were increasingly difficult to identify as their size decreased. Fire danger rating in Portugal is based on the Fire Weather Index (FWI) of the Canadian Forest Fire Weather Index System. Each large fire was attributed with a fire danger class after the FWI from the nearest weather station was averaged for the length of the fire. Survival analysis considered two subsets of observations defined by a FWI threshold of 38.2, which distinguishes between fires under non-extreme and extreme fire weather based on potential fire intensity and suppression difficulty (Palheiro et al. 2006).

Table 1. Median fire-free interval (MEI) and Weibull parameters $b$ and $c$ (with $95 \%$ confidence intervals) for the fire frequency analysis. $n=$ number of fires

\begin{tabular}{|c|c|c|c|c|c|c|c|c|c|}
\hline \multirow[t]{2}{*}{ Ecoregion } & \multicolumn{5}{|c|}{ Complete + censored } & \multicolumn{4}{|c|}{ Complete } \\
\hline & $n$ & $\%$ cens. & MEI & $b$ & $c$ & $n$ & MEI & $b$ & $c$ \\
\hline NW Cismontano & 2497 & 37.0 & 22.9 & $\begin{array}{c}28.1 \\
(27.8-28.4)\end{array}$ & $\begin{array}{c}1.80 \\
(1.78-1.83)\end{array}$ & 1572 & 14.3 & $\begin{array}{c}16.5 \\
(16.4-16.6)\end{array}$ & $\begin{array}{c}2.62 \\
(2.58-2.65)\end{array}$ \\
\hline Alto Portugal & 1709 & 46.4 & 27.3 & $\begin{array}{c}33.7 \\
(33.3-34.1)\end{array}$ & $\begin{array}{c}1.73 \\
(1.70-1.76)\end{array}$ & 913 & 15.2 & $\begin{array}{c}17.4 \\
(17.3-17.6)\end{array}$ & $\begin{array}{c}2.66 \\
(2.62-2.70)\end{array}$ \\
\hline NE Transmontano & 1409 & 41.4 & 28.3 & $\begin{array}{c}34.1 \\
(33.7-34.5)\end{array}$ & $\begin{array}{c}1.95 \\
(1.91-1.99)\end{array}$ & 826 & 17.0 & $\begin{array}{c}19.3 \\
(19.1-19.5)\end{array}$ & $\begin{array}{c}2.85 \\
(2.80-2.90)\end{array}$ \\
\hline Beira Douro & 1050 & 30.1 & 18.4 & $\begin{array}{c}22.9 \\
(22.7-23.2)\end{array}$ & $\begin{array}{c}1.66 \\
(1.64-1.69)\end{array}$ & 734 & 12.8 & $\begin{array}{c}14.8 \\
(14.6-14.9)\end{array}$ & $\begin{array}{c}2.46 \\
(2.43-2.50)\end{array}$ \\
\hline Beira Alta & 525 & 33.1 & 26.8 & $\begin{array}{c}32.2 \\
(31.8-32.7)\end{array}$ & $\begin{array}{c}1.98 \\
(1.93-2.03)\end{array}$ & 351 & 17.0 & $\begin{array}{c}20.0 \\
(19.7-20.3)\end{array}$ & $\begin{array}{c}2.26 \\
(2.21-2.31)\end{array}$ \\
\hline Beira Serra & 962 & 35.1 & 28.9 & $\begin{array}{c}34.5 \\
(34.3-34.8)\end{array}$ & $\begin{array}{c}2.07 \\
(2.05-2.10)\end{array}$ & 624 & 18.2 & $\begin{array}{c}20.4 \\
(20.3-20.5)\end{array}$ & $\begin{array}{c}3.16 \\
(3.12-3.20)\end{array}$ \\
\hline Estremadura & 598 & 70.0 & 46.6 & $\begin{array}{c}52.2 \\
(51.1-53.4)\end{array}$ & $\begin{array}{c}3.22 \\
(3.10-3.34)\end{array}$ & 179 & 19.2 & $\begin{array}{c}21.5 \\
(21.1-21.9)\end{array}$ & $\begin{array}{c}3.28 \\
(3.15-3.41)\end{array}$ \\
\hline All & 10197 & 47.0 & 34.7 & $\begin{array}{c}43.1 \\
(42.9-43.4)\end{array}$ & $\begin{array}{c}1.69 \\
(1.68-1.71)\end{array}$ & 5399 & 16.0 & $\begin{array}{c}18.4 \\
(18.3-18.5)\end{array}$ & $\begin{array}{c}2.59 \\
(2.58-2.61)\end{array}$ \\
\hline
\end{tabular}

\section{Results}

The Portuguese fire atlas (1998-2008) contains 10,197 fires $\geq 9.5$ ha, corresponding to a sum of $1.65 \times 10^{6}$ ha and a mean annual burned surface of $1.5 \times 10^{5}$ ha. Sizes of the largest, mean and median fires are respectively 66,071, 162 and 31 ha.

Table 1 displays the results of the regional fire frequency analysis. Ecoregions with $>75 \%$ censoring are omitted, corresponding to a threshold above which unrealistically high shape parameters were possible $(5<c<15)$. Regional overlapping between the $95 \%$ confidence intervals for the Weibull parameters is very low. However, the typical FRI and MEI values vary within relatively narrow ranges of 23-34 and 18-29 years in all but one ecoregion. The shape parameter for those regions denotes near-linear growth of 
burning likelihood with time, varying from 1.7 to 2.1. In contrast, the Estremadura region is characterized by a longer fire-free period $(b=52$ years, MEI $=47$ years) and exponential timedependency of the fire regime $(c=3.2)$.

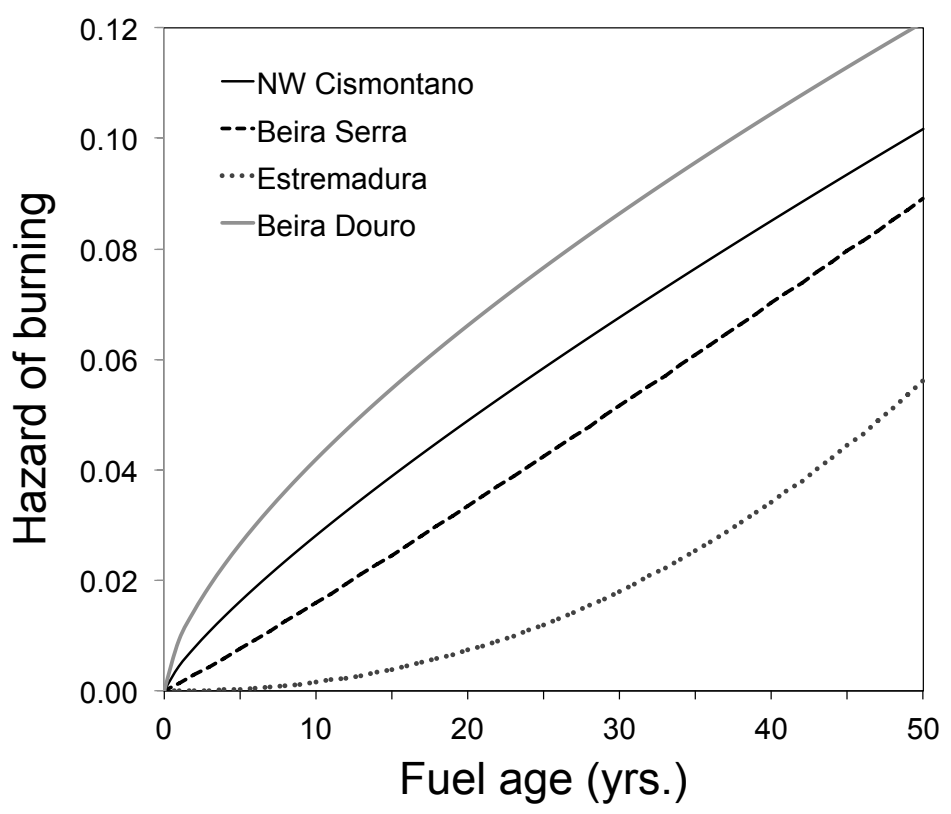

Fig. 1. Change in hazard of burning with time for four selected ecoregions in Portugal.

The hazard functions for four selected regions are shown in Fig. 1, including those with the more disparate $b$ and $c$ parameters, i.e. Beira Douro (the shortest fire interval and the lowest age dependency) and Estremadura. Regardless of its rate of increase, hazard of burning remains low throughout the sampled time-since-fire range and beyond. The likelihood of burning is below that of an age-independent system (i.e. $c=1$ ) for 10 to 17 years after fire, except in Estremadura (30 years).

The sole use of complete observations in the fire frequency analysis results in shorter and less variable fire intervals and higher fuel age dependency. On average, $b$ and MEI decrease by a factor of 0.6 and $c$ increases by a factor of 1.4, varying now in the ranges of 15 to 21 years, 13 to 19 years and 2.3 to 3.3 , respectively (Table 1 ).

Hazard of burning is affected by fire size, with increasingly large fires being more likely to burn over young fuels (Table 2). The effect is robust, as judged by the non-overlapping $95 \%$ confidence intervals for the estimates of $c$ for the fire size pairs in Table 2. Nevertheless, the effect is small, and fuel age dependency is still expressed by an approximately linear increase with time, regardless of the cut-off fire size used in the comparison. Also, the difference between the $c$ parameters of each pair decreases as the fire size threshold for comparison increases and ceases to exist at the 500-ha threshold.

Limitations in the cross-referencing methodology restricted the retrieval of fire danger rating data to respectively $30.1 \%$ and $61.3 \%$ of the large ( $\geq 100 \mathrm{ha}$ ) fires number and area. For this representative sample, we found that areas burned by large fires driven by extreme weather correspond to slightly lower fuel age dependency (Table 2), hence supporting the assumption that $c$ responds to fire size because of the effect of more severe weather. However, the larger fire group and the more extreme fire weather group always have higher $b$ values for each comparison in Table 2 . This implies that, on average, fires under more severe burning conditions consistently select for older fuels. 
Table 2. Weibull parameters ( $b$ and $c$ ) with $95 \%$ confidence intervals for the fire frequency analysis by fire size class $(n=10197)$ and fire danger rating $(n=668$, fires $\geq 100$ ha) for complete plus censored observations.

\begin{tabular}{rcccc}
\hline Data set & & $n$ & $b$ & $c$ \\
\hline Fire size (ha) & & & & \\
& $\geq 25$ & 4217 & $36.9(36.2-37.7)$ & $2.09(2.02-2.16)$ \\
& $\geq 25$ & 5980 & $43.4(43.2-43.6)$ & $1.68(1.67-1.70)$ \\
\hline & $<50$ & 6443 & $35.9(35.4-36.4)$ & $1.97(1.92-2.01)$ \\
$\geq 50$ & 3754 & $43.9(43.6-44.1)$ & $1.67(1.66-1.69)$ \\
\hline$<100$ & 5399 & $34.2(33.8-34.5)$ & $1.85(1.82-1.88)$ \\
$\geq 100$ & 2219 & $45.0(44.7-45.2)$ & $1.67(1.66-1.69)$ \\
\hline$<250$ & 9178 & $33.2(33.0-33.5)$ & $1.78(1.76-1.80)$ \\
$\geq 250$ & 1019 & $47.5(47.2-47.8)$ & $1.68(1.67-1.70)$ \\
\hline$<500$ & 9689 & $32.4(32.2-32.6)$ & $1.74(1.73-1.76)$ \\
$\geq 500$ & 508 & $51.1(50.7-51.6)$ & $1.73(1.71-1.74)$ \\
\hline Fire danger rating & & & & \\
Non-extreme & 328 & $28.4(28.2-28.7)$ & $1.91(1.89-1.94)$ \\
Extreme & 340 & $55.9(55.3-56.5)$ & $1.78(1.76-1.80)$ \\
\hline
\end{tabular}

\section{Discussion}

While typical fire intervals are somewhat variable (roughly in the 10-50 years range), the timedependency of burn probability in Mediterraneantype shrublands is generally characterized as weak to moderate, with $c<2.5$ (Polakow and Dunne 1999; Moritz 2003; Moritz et al. 2004; Van Wilgen et al. 2010; O'Donnell et al. 2011). Our study results fit this pattern, but if the survival analysis is restricted to uncensored observations then fuel age dependency increases, as previously noted by Moritz et al. (2009).

Incomplete fire intervals contain useful information that fire frequency analysis should retain (Polakow and Dunne 1999; Moritz et al. 2009). However, from a management perspective, fire dynamics may be more adequately portrayed by the analysis based on recurrent fires. The relevance of censored observations is diminished in view of the relatively recent and dramatic increase of fire incidence in Portugal, e.g. the mean annual area burned on public land in 19751980 (Macedo and Sardinha 1993) and 1990-1999 (Rego 2001) increased respectively 6 and 12 times since 1943-1974. Studies in Spain show that recurrently burnt areas tend to be spatially aggregated (Vázquez and Moreno 2001; DíazDelgado et al. 2004; Salvador et al. 2005). At subregional to local scales, complete fire intervals are more likely to match those areas where fire is perceived as a threat and where fuel treatment programs will be implemented. Finally, complete fire intervals should provide more realistic information on the worth of fuel management under climate change scenarios that are expected to increase fire frequency.

Typical FRI and MEI values modelled from complete observations primarily reflect the fire regime of shrubland and regenerating forest and are coherent with fuel dynamics described for shrubland in Portugal, e.g. Fernandes and Rego (1998); the increase in flammability with fuel age is sharp but relatively short-lived, as fine fuel loads and modelled fire behaviour in these systems stabilize within 10 to 20 years after fire.

The hazard of burning is normally affected by several factors exogenous to fuel dynamics, including variation in landform, fire weather, ignition rates and the overall fire management effort. However, regional variation in the hazard of burning function was relatively low, regardless of the variation in fire dynamics potentially induced by the above-mentioned factors. The Estremadura region diverges by exhibiting marked fuel age dependency that can be ascribed to a combination of lower ignition density, less rugged topography and lower productivity. Additionally, limestone substrates occupied by shrublands that are less flammable than the heathlands typical of siliceous soils (Fernandes et al. 2004) are well represented in this ecoregion. In contrast, fuel age dependency is lowest in north-western Portugal, particularly in Beira Douro, where occupational burning of mountain heathlands for pastoral purposes is widespread and higher rainfall promotes faster fuel accumulation. By increasing the grass component, 
the recurrence of fire may promote a fuel complex that will burn more readily and will support even more frequent fire, e.g. Vilá et al. (2001).

Extreme fire weather is usually expected to prevail over the effect of fuel on landscape fire spread (Fernandes and Botelho 2003; Moritz 2003; Keeley and Zedler 2009). Time-dependency of burn probability in this study was influenced by weather conditions, both directly and as inferred from fire size, but the effect was small, suggesting that the performance of fuel treatments does not degrade substantially under unfavourable weather scenarios. Alternatively, minor changes in the $c$ parameter for increasingly large fires may reflect inefficient fire control under mild weather. Fire suppression in Portugal neglects perimeter control (Beighley and Quesinberry 2004) and is concentrated along roads and at wildland-urban interfaces and therefore is unlikely to benefit from fuel-related changes in fire behaviour. Dispersion of resources and poor organization exacerbate this when fires escape initial attack. Consequently, the results suggest that more efficient fire control operations would increase fuel-age dependency.

Limitations of fuel management in constraining wildfire area are made evident by the results, similarly to other shrub-dominated Mediterranean ecosystems characterized by high-intensity crown fires (Keeley 2002; Price and Bradstock 2010; Van Wilgen et al. 2011). Moderate fuel-age dependency indicates that fuel management programs based on strategically located linear treatments are likely to achieve lower cost-tobenefit ratios than area-wide treatments. On the other hand, larger fires and extreme weather conditions correspond with older fuels (Table 2), where fire suppression is made more difficult by higher fuel loadings. The concurrent increase of $b$ with the decrease in $c$ can be an expression of increasingly higher connectedness between old fuel patches. This is consistent with studies in Portugal (Vilén and Fernandes 2011) and Australia (Boer et al. 2009; Price and Bradstock 2011) that modelled annual fire extent from weather and previous years' area burned. Shrubland-dominated landscapes in the Mediterranean Basin are comparatively more fragmented than in California, Australia or South Africa, and the existing land use diversity and easy access to wildlands favour higher ability of fire suppression to take advantage of the fuel age mosaic. The results should be supplemented by other modelling approaches, namely by analysing how young fuels truncate fire spread (Price and Bradstock 2010).

\section{Acknowledgments}

The European Commission project FIRE PARADOX (FP6-018505) funded this study. We thank Samantha Jane-Hughes for text editing and acknowledge the significant improvements brought by the comments of Max Moritz, José Cardoso Pereira and one anonymous reviewer. Autoridade Florestal Nacional (AFN), the Portuguese Forest Service, provided all data.

\section{References}

Albuquerque JPM (1961) Divisão regional do Continente Português. Agricultura 9, 1-11.

Beighley M, Quesinberry M (2004). 'USA-Portugal Wildland Fire Technical Exchange Project - Final Report' (USDA Forest Service)

Boer MM, Sadler RJ, Bradstock RA, Gill AM, Grierson PF (2008) Spatial scale invariance of southern Australian forest fires mirrors the scaling behaviour of fire-driving weather events. Landscape Ecology 23, 899-913.

Boer MM, Sadler RJ, Wittkuhn R, McCaw L, Grierson PF (2009) Long-term impacts of prescribed burning on regional extent and incidence of wildfires evidence from fifty years of active fire management in SW Australian forests. Forest Ecology and Management 259, 132-142.

Bradstock RA (2010) A biogeographic model of fire regimes in Australia: current and future implications. Global Ecology and Biogeography 19, 145-158.

Camia A, Amatulli G (2009) Weather factors and fire danger in the Mediterranean. In Chuvieco E (Ed.) 'Earth Observation of Wildland Fires in Mediterranean Ecosystems'. pp. 71-82 (SpringerVerlag: Berlin)

Carvalho A, Flannigan MD, Logan K, Miranda AI, Borrego C (2008) Fire activity in Portugal and its relationship to weather and the Canadian Fire Weather Index System. International Journal of Wildland Fire 17, 328-338.

Díaz-Delgado R, Lloret F, Pons X (2004) Statistical analysis of fire frequency models for Catalonia (NE Spain, 1975-1998) based on fire scar maps from Landsat MSS data. International Journal of Wildland Fire 13, 89-99.

Fernandes P, Rego F (1998) Changes in fuel structure and fire behaviour with heathland aging in Northern Portugal. In 'Proceedings of the 13th Conference on 
Fire and Forest Meteorology. pp. 433-436. (International Association of Wildland Fire)

Fernandes PM, Botelho HS (2003) A review of prescribed burning effectiveness in fire hazard reduction. International Journal of Wildland Fire 12, 117-128.

Fernandes $\mathrm{P}$, Botelho H, Cohen M, Cuiñas P, Dupuy JL, Fonturbel T, Loureiro C, Maréchal J, Petit P, Pérez-Gorostiaga P, Portier D, Rigolot E, Ruas L, Valette JC, Vega JA (2004) Fire Star field fires: second campaign. D7-05. FIRE STAR: a decision support system for fuel management and fire hazard reduction in Mediterranean wildland - urban interfaces (EVG1-CT-2001-00041).

Grissino-Mayer HD (1999) Modeling fire interval data from the American Southwest with the Weibull distribution. International Journal of Wildland Fire 9, 37-50.

Hoinka KP, Carvalho A, Miranda AI (2009) Regionalscale weather patterns and wildland fires in central Portugal. International Journal of Wildland 18, 36 49.

Johnson E., Gutsell SL (1994) Fire frequency models, methods, and interpretations. Advances in Ecological Research 25, 239-287.

Keeley JE (2002) Fire management of California shrubland landscapes. Environmental Management 29, 395-408.

Keeley JE, Zedler PH (2009) Large, high-intensity fire events in southern California shrublands: debunking the fine-grain age patch model. Ecological Applications 19, 69-94.

Macedo FW, Sardinha AM (1993) 'Fogos Florestais'. (Publicações Ciência e Vida Lda: Lisboa)

Minnich RA (1983) Fire mosaics in Southern California and Northern Baja California. Science 219, 1287 124.

Moritz MA (2003) Spatiotemporal analysis of controls on shrubland fire regimes: age dependency and fire hazard. Ecology 84, 351-361.

Moritz MA, Keeley JE, Johnson EA, Schaffner AA (2004) Testing a basic assumption of shrubland fire management: how important is fuel age? Frontiers in Ecology and the Environment 2, 67-72.

Moritz MA, Tadashi JM, Miles LJ, Smith MM, de Valpine P (2009) The fire frequency analysis branch of the pyrostatistics tree: sampling decisions and censoring in fire interval data. Environmental and Ecological Statistics 16, 271-289.

Moritz MA, Moody TJ, Krawchuk MA, Hughes M, Hall A (2010) Spatial variation in extreme winds predicts large wildfire locations in chaparral ecosystems. Geophysical Research Letters 37, L04801.

Nunes MCS, Vasconcelos MJ, Pereira JMC, Dasgupta N, Alldredge RJ, Rego FC (2005) Land cover type and fire in Portugal: do fires burn land cover selectively? Landscape Ecology 20, 661-673.

O'Donnell AJ, Boer MM, McCaw WL, Grierson PF (2011) Vegetation and landscape connectivity control wildfire intervals in unmanaged semi-arid shrublands and woodlands in Australia. Journal of Biogeography 38, 112-124.

Palheiro PM, Fernandes P, Cruz MG (2006) A fire behaviour-based fire danger classification for maritime pine stands: comparison of two approaches. Forest Ecology and Management 234 suppl. $1 \mathrm{~S} 54,15$.

Pereira JMC, Santos TN (2003) 'Fire Risk and Burned Area Mapping in Portugal'. (Direcção Geral das Florestas: Lisboa)

Pereira MG, Trigo RM, da Camara C, Pereira JMC, Leite SM (2005) Synoptic patterns associated with large summer forest fires in Portugal. Agricultural and Forest Meteorology 129, 11-25.

Polakow DA, Dunne TT (1999) Modelling fire-return interval $\mathrm{T}$ : stochasticity and censoring in the twoparameter Weibull model. Ecological Modelling 121, 79-102.

Price OF, Bradstock RA (2010) The effect of fuel age on the spread of fire in sclerophyll forest in the Sydney region of Australia. International Journal of Wildland Fire 19, 35-45.

Price OF, Bradstock RA (2011) Quantifying the influence of fuel-age and weather on the annual extent of unplanned fires in the Sydney region of Australia. International Journal of Wildland Fire 20,142-151.

Rego FC (2001) 'Florestas Públicas' (MADRP: Lisboa)

Salvador R, Lloret F, Pons X, Piñol J (2005) Does fire occurrence modify the probability of being burned again? A null hypothesis test from Mediterranean ecosystems in NE Spain. Ecological Modelling 188, 461-469.

Van Wagner C (1987) 'Development and structure of the Canadian Forest Fire Weather Index System'. Canadian Forestry Service, Forestry Technical Report 35. (Otawa)

Van Wilgen BW, Forsyth GG, De Klerk H, Das S, Khuluse S, Schmitz P (2010) Fire management in Mediterranean-climate shrublands: a case study from the Cape fynbos, South Africa. Journal of Applied Ecology 47, 631-638.

Vázquez A, Moreno JM (2001) Spatial distribution of forest fires in Sierra de Gredos (Central Spain). Forest Ecology and Management 147, 55-65.

Vilà M, Lloret F, Ogheri E, Terradas J (2001) Firegrass feedback in Mediterranean Basin woodlands. Forest Ecology and Management 147, 3-14.

Vilén T, Fernandes PM (2011) Forest fires in Mediterranean countries: $\mathrm{CO}_{2}$ emissions and mitigation possibilities through prescribed burning. Environmental Management. doi: 10.1007/s00267011-9681-9.

Zea Bermudez P, Mendes J, Pereira JMC, Turkman KF, Vasconcelos MJP (2009) Spatial and temporal extremes of wildfire sizes in Portugal (1984-2004). International Journal of Wildland Fire 18, 983-991. 